\title{
Catherine of Siena's crusade letters: Spirituality and political context
}

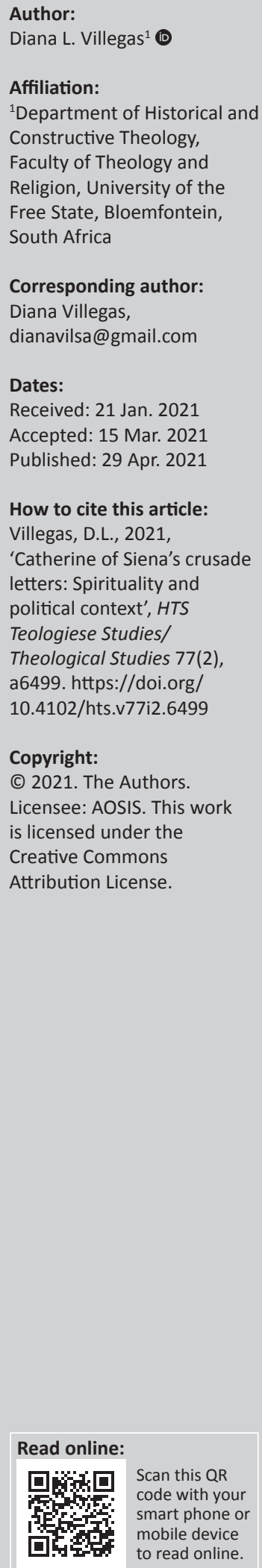

Catherine of Siena has been credited with original views regarding the crusade as political policy and with influencing Gregory XI to carry this out. In this article, I argued that while Catherine of Siena did not succeed in furthering the crusade - nor did she initiate this policy her crusade correspondence leaves us a legacy that reveals significant aspects of her spirituality. Over 40 letters to ecclesiastical authorities, Kings, Queens, leaders of city states, knights and her own followers reveal a religious intent, although addressing a policy with both religious and political consequences. The latter were important to Catherine because she considered politicalcultural context vital for salvation and transformation; she advocated for the crusade because she considered that the crusade pilgrimage and holy war to recover the Holy Land would be critical for the salvation of many. Her epistles further witness to the prophetic, missionary nature of Catherine's spirituality, and we see how she crafted her own version of crusade spirituality out of the wisdom on transformation learned through her union with God, fused with early Christian martyr spirituality and early crusade spirituality preached in medieval Europe. This thematisation of Catherine's crusade letters is based on textual analysis of all crusade related letters in the 2002 critical text, on the most complete dating of Catherine's letters (finished in 2008); and in dialogue with literary and other historical advances, making it an innovative study.

Contribution: Catherine of Siena's crusade letters reveal significant aspects of her spirituality rather than contributions to crusade politics. The letters evidence her prophetic-missionary spirituality and her conviction that socio-political context is significant for a journey of transformation; as well, this analysis details the importance of early Christian martyr spirituality for Catherine's crusade spirituality.

Keywords: Catherine of Siena and crusades; crusade spirituality; spirituality and politics; Catherine of Siena letters; spiritual transformation and cultural context.

\section{Introduction}

Catherine of Siena's crusade letters reveal a spirituality that considered social and political realities as significant contexts for a journey of transformation, and they disclose the way Catherine wove together her innovative version of crusade spirituality. In this article, I argue that her crusade correspondence reveals the significant aspects of Catherine's spirituality rather than any gift for crafting and/or advancing papal policies or influencing persons in power.

Tradition has credited Catherine with initiating and/or influencing Gregory XI's crusade politics. Early hagiographers, intent on promoting her beatification and eventual canonisation, interpreted her passionate advocacy as persuading Gregory XI to start a crusade. ${ }^{1}$ This early reputation was furthered by Catherine's crusade correspondence since it included ecclesiastical and temporal authorities. She wrote nine letters to Gregory $\mathrm{XI}^{2}{ }^{2}$ two to Urban $\mathrm{VI}^{3}{ }^{3}$ and over 30 more to Kings, Queens, leaders of city states and knights, as well as a few to her own followers.

\footnotetext{
1.In the most influential hagiography, Raymond of Capua, Dominican advisor to Catherine, wrote 'Catherine always desired that the crusade take place and she worked very hard to accomplish this desire', and attributed to Catherine success in persuading the pope to pursue this cause (Raymond of Capua 1980:section 291) [my translation of Italian edition]. For a historical analysis of influences on the construction of this hagiography, see Coakley (2006:chp. 1, 9, 11).

2.Letters to Gregory XI were analysed in the first of this series of three articles - this is the second - regarding Catherine of Siena's political engagement and her spirituality (Villegas 2021).

3.After Gregory XI died, Catherine wrote to Urban VI (Letter 291) encouraging him to continue the crusade, though at this point the effort was failing. In a second letter (351) from 1379, Catherine suggested, 'raising the standard of the cross' over the 'unbelievers' as part of a comprehensive plan to reform the church. At that time Urban VI was engaged in struggles with Clement VII, so a crusade made no sense. I interpret these 1379 passages as further evidence of the argument of this essay regarding the importance Catherine placed on the salvific value of crusade. References to letter numbers based on the critical edition by A. Volpato (Catherine of Siena 2002), which uses the T (Tommaseo) numbering; this numbering, with noted exceptions, is followed in Noffke's English translation (Catherine of Siena 2000-2008), where letters are published in historical order.
} 
Catherine's reputation as influential in crusade politics has also been fostered by analyses both in general histories ${ }^{4}$ and in dedicated essays. The latter have appeared primarily in the Italian and French historical literature exploring how Catherine's views fit into perspectives on the crusade, examining questions such as: did Catherine argue that peace was necessary for a crusade or a crusade for peace ${ }^{5}$ A recent Italian article argued that while Catherine's teaching on the crusade was not new, her assertion that one of the benefits of the crusade would be the conversion of 'unbelievers' ${ }^{6}$ was innovative (Viglione 2014), a view contradicted by Luongo (2006:172, n. 151).

Catherine did not initiate the papal causes in which she became involved. Rather, following a medieval tradition, ecclesiastical authorities chose her for the role of prophetic counsellor and advocate for papal policies (Villegas 2021: 2-4), including the crusade, a cause that never took off and eventually failed. ${ }^{7}$ Despite her letters to Gregory XI, there is no evidence that Catherine had much influence on his crusade policy. ${ }^{8}$ We shall see that she did not influence the policy decisions of her correspondents.

If Catherine did not influence crusade policy, what is the significance of her crusade correspondence? This correspondence reveals important aspects of Catherine's spirituality. Most uniquely, we see Catherine's belief that salvation/transformation not only was an individual matter but also was underpinned by the social order and church structure. Thus, a political cause could create societal changes and opportunities relevant to salvation. A crusade would make peace possible; peace would leave the pope freer to reform the clergy and focus on ordering the church's activity for the salvation of others. ${ }^{9}$ Peace would lead knights away from the sinful activity of fighting among brothers. ${ }^{10}$ As well, the crusade would offer the possibility of salvation to crusaders and any others who would join this holy pilgrimage. Finally, the recovery of the Holy Land would offer the possibility of salvation to those 'unbelievers' who could be converted. Catherine, then, advocated for a policy that was at once political and religious because she believed the cause was important to salvation; her intent was religious while

4.For instance, Luongo (2006) in his influential recent work argues that Catherine exercised political agency and refers to her involvement in the crusade (see also Vauchez 2018:39-43,50). See Luongo (2012) for a history of the reception over time of accounts regarding Catherine's advocacy for ecclesiastical policies.

5.For instance, see Rousset (1975). For a list of important historical essays since the mid-20th century, see Viglione (2014:92-93).

6.I use the term unbelievers for consistency with Catherine's usage in her 14thcentury context.

7.See Thiebault (1985) for the history of Gregory XI's crusade; Thiebault (1985: 334-335) also provides a summary of the crusade's failure.

8.Gregory XI wanted a crusade since he was consecrated pope, before Catherine became involved in this cause. The execution of his crusade policy depended on multiple ecclesiastical and temporal authorities with varying power interests. See Thiebault (1985).

9.The cause of peace and reform of the church as central to salvation is discussed in the first article of this series (Villegas 2021:5-7).

10.Catherine considered fighting among fellow Europeans to be sinful. See Letter 140 to Hawkwood and Letter 235 to Charles V. believing in the importance of social context for the spiritual journey. ${ }^{11}$

Catherine's crusade letters also show she created her own version of crusade spirituality by fusing it with early Christian martyr spirituality, which she highlighted; she then merged this fusion with the wisdom about transformation for which she is known. Furthermore, these letters evidence Catherine's creative individualisation of her wisdom regarding the centrality of a personal relationship with God to accurately perceive what one should do and then be able to carry it out. As well, this set of letters demonstrates a dimension of Catherine's spirituality that is not often noted, namely, her spirituality of vocation.

To my knowledge, the thematisation of Catherine's crusade spirituality elaborated below, which includes an overview of all her crusade letters, has not been offered elsewhere.

\section{Catherine's crusade spirituality}

Catherine's epistles, including those requesting material assistance for Gregory XI's crusade, were driven by a passionate desire for persons' transformation. She expressed a 'hunger' for their salvation and explains that this 'hunger' is the reason for the extensive exhortations that contextualise her requests for crusade support. She tells Regina della Scala, 'Forgive me if I have weighed you down with my words: I do it because of love and the resulting hunger for your salvation' (Letter 29; discussed below). ${ }^{12}$ Accordingly, all of Catherine's letters included elements of her wisdom about a transforming relationship with God, her central concern. Through time spent in silence and solitude, persons should seek to know God's love and mercy in an experiential way, at the same time that they faced weaknesses, sinfulness and limitation, that is, their need for God. God's response to persons' need would fuel conviction about God's unconditional, merciful love. This inner experience must be nurtured by participation in the liturgy of the Hours and Mass. Such a spiritual path would transform a person's capacity for charity (love), that is, capacity to give of self for the good of the other. Transformed love emerges from transformed desire, that is, our affectivity is changed through the encounter with God, so that which emerges from the depths of our being (desire) will be more and more congruent with God's love and truth. ${ }^{13}$

This general wisdom became intertwined with Catherine's version of crusade spirituality which also underscored the

11. Historian Beattie (2011:78) interprets Catherine's belief about the connection between the individual and the social as showing that acts considered spiritual were at the same time political. For a literary study of Catherine's versus Raymond's metaphors on Catherine's religious reasons for political causes see (Barrett \& Lukowski 2008). Gregory XI through his request for help from Tuscan ecclesiastical and temporal authorities (discussed below) and those who coached Catherine undoubtedly privileged political intent.

12.Based on A. Volpato's critical edition (Catherine of Siena 2002), translations are mine with the goal of rendering as literally as possible Catherine's metaphors and passionate language in preference to rendering the best English prose. Volpato offers updated notes and edits in an online edition; see Catherine of Siena (2016).

13.For a thematisation of Catherine's wisdom regarding a transforming relationship with God, see Noffke (1996:23-38; Villegas 2017). For her focus on knowledge of God and self, see McDermott (2007). 
value of transformation. Crusades started as penitential pilgrimages, where both knights and other pilgrims pursued penance, fasting and prayer as they travelled to Jerusalem, centre of the salvific Christ event. The military goal of delivering the Holy Land from the 'unbelievers' was also considered a transformative pilgrimage when undertaken with the due religious practices and penitential attitude. ${ }^{14}$ Catherine would have been formed by writings about the crusade such as the sermons of Bernard of Clairvaux, wellknown Cistercian monk and medieval theologian. ${ }^{15}$ Works such as his sermons were undoubtedly preached and read at the daily services she attended. ${ }^{16}$

\section{Transformation and martyrdom}

The willingness to die for the good of the church in the course of the pilgrimage to liberate the Holy Land was a feature though not central - to crusade spirituality. It was an ideal related to, but distinct form the spirituality of martyrdom, a tradition whose language and ideals became central to Catherine's crusade spirituality. Martyrdom was considered the perfection of charity (love) and the ultimate way of attaining union with Christ (Bouyer 1960:256, chp. 8, French edn.). Dying as a martyr witnessed to profound faith in Christ's resurrection, the supreme triumph of faith over evil, and witnessed to Christ's eucharistic sacrifice, the giving of his life for us (Bouyer 1960:252-253, chp. 8, French edn.; Rordorf \& Solignac 1980:pt II). Given these beliefs, early church spirituality featured a desire for martyrdom as a sign of growth in the spiritual journey (Rordorf \& Solignac 1980:pt III). Many of these early Christian texts were read during the Liturgy of the Hours and the Mass for the feasts of martyrs, thus influencing not just Catherine but also Christian spirituality for hundreds of years (Bouyer 1960:239-240, chp. 8, French edn.).

Catherine's attraction to, and adoption of, the language of martyrdom, which we will see is prominent in her letters, is undoubtedly the result of her own spiritual journey. Shedding her blood for love of Christ had captured her imagination and spurred her desire since her early days of solitude. ${ }^{17}$ Her theology and spirituality are filled with the symbol of the blood and much has been written about this. ${ }^{18}$ She repeatedly wrote of a deep desire for martyrdom and prayed she be granted the gift to show Christ her total love in this way. ${ }^{19}$ Accordingly, it is not surprising that she was drawn to the crusade as a way of achieving this ideal of martyrdom, which

14. In the early crusades prayer and fasting were common before engaging in battle. On crusade spirituality, see Blake (1970); Merton (2008); Portnykh (2017).

15.On Bernard of Clairvaux's crusade spirituality, see Flood (1974:35) summarises these teachings.

16.Raymond (1980:section 113) describes Catherine's reading of material in Italian related to the Liturgy of the Hours. See Villegas (2013:210-212) on Catherine's mostly oral formation.

17.Raymond (1980:section 63) describes that in her adolescent years, Catherine sought to offer 'blood for blood' to Jesus by engaging in penances that drew blood.

18.For a selection of Catherine's views on the blood of Christ, see Noffke (20112012:87-110, vol. 2). On her spirituality of the blood, see McDermott (2008:8489) and McGinn's (2012) chapter on Catherine, 'Catherine of Siena, mystical apostle of the blood of Christ' in (pp. 197-249).

19.For instance, see Letter 226 to Raymond, her spiritual advisor about transformation through embracing the cross and her desire for martyrdom. See Noffke's antholog for passages from other letters (above note). for her represented the highest expression of love for Christ. We will see that Catherine encouraged all her correspondents, whether mercenary soldiers or sinful monarchs, to desire to give their lives for Christ through a crusade pilgrimage. The metaphor rich oral rhetoric ${ }^{20}$ of Catherine's letters is, then, a fusion of martyr and crusade spirituality merged with her wisdom about transformation.

\section{The letters}

Catherine's letters to disciples and spiritual advisors focus on urging them to show their love for Christ through the holy passage pilgrimage ${ }^{21}$ and the related opportunity for martyrdom. Letters to knights, soldiers and civil authorities pressed these strategically selected persons to advocate for support of Gregory XI's crusade effort.

\section{To disciples and spiritual advisors Dalla Fonte and Flete}

Dominican friar Tommaso dalla Fonte, a childhood friend, and William Flete, Augustinian monk, were both especially close and dear to Catherine. As learned churchmen, they contributed to her religious formation through her years of dialogue with them. She wrote to both about her desire to go on crusade as a path to martyrdom and urged them to seek this ideal.

Flete should give his life in martyrdom as response to Jesus' gift of himself on the cross:

May God give us the grace of hearing our prayer to see us give our life for the immeasurable love of the Lamb ... Oh! Let's race, my brothers and sons in Christ Jesus, may we raise sweet and loving desires that will beg and press the divine goodness to soon make us worthy of this grace [martyrdom]. (Letter 66, [author's own italics])

It would give her great joy, Catherine tells Flete, if her followers and friends would 'run as persons in love to give your life without turning back' (Letter 66).

To dalla Fonte, she wrote urging participation in the crusade and prayed he receive the grace to obtain martyrdom: 'I pray that sweetest Light [Jesus] might lead us to bleed to death for the truth' (Letter 283).

\section{Mantellate - Prioress}

Catherine communicated the same exhortation to women disciples. To her fellow mantellate, ${ }^{22}$ she narrated a visit from an envoy to the Queen of Cyprus on crusade business, telling them crusade preparations were progressing 'from good to better'. She then exhorted the mantellate to 'stock the boat of your soul, as your time is coming' [to go on crusade] (Letter 132).

20.Catherine's letters were dictated as she learned to read as an adult and perhaps to write towards the end of her life.

21.The term crusade appeared in the 15th century. In Catherine's day, the crusade was referred to as 'holy passage', a form of penitential pilgrimage. See Pernoud (1991).

22.Term used for the penitential lay order of women (not a religious order) to which Catherine belonged; it was under the spiritual guidance of the Dominicans. 


\section{To Paola, a prioress, she writes:}

Let us all as a brigade run and graft ourselves onto this Word. I invite you to the wedding feast of this grafting, that is, to shed our blood for him, as he shed it for you; let's go to the Holy Sepulchre, and let's leave our life for Him there. (Letter 144, [author's own italics])

Going on crusade to one's martyrdom is like going to a wedding, in other words a joyous and life altering celebration. At this celebration, we are united to Christ by giving our blood.

These communications highlight that Catherine's crusade spirituality was couched in the language of martyr spirituality. Significantly, they show that the ideal of giving one's life in martyrdom was not just aspirational. For Catherine considered it a realistic option that monks, prioresses, mantellate and she herself could go on pilgrimage to the Holy Sepulchre, to the sites where Jesus gave himself for us. These values had such pre-eminence in her spirit and imagination that she did not seem conscious of their impracticality. Indeed, Giovanni dalle Celle, a hermit who was one of Catherine's supporters and spiritual correspondents, warns one of his spiritual followers against plans to go to the Holy Land based on encouragement from Catherine. Giovanni tells her this is a dangerous and inappropriate project for a cloistered woman (Viglione 2014:95).

\section{To knights and soldiers}

Catherine told three different correspondents that the pope wrote to Raymond and to the Dominican and Franciscan Provincials asking them to promote the cause of the crusade in Tuscany (Letters 131, 133 and 144): $:^{23}$

The Holy Father, our Christ on earth, wants to know the disposition and will of Christians to give their lives in order to recover the Holy Land ... This is stated in the Bull he sent to our provincial, to that of the Franciscans and to Brother Raymond. He asked them to look into the availability of persons throughout Tuscany and other territories. He wants to know in writing the level of willingness and how many will be involved in order to issue the relevant order and make sure it is carried out. (Letter 131, [author's own italics])

We see that Catherine interprets Gregory XI's directive to enlist help for his crusade as a call to a spirituality of crusade, with her own unique emphasis on martyr spirituality. At the same time, undoubtedly under Raymond's guidance, she knew the pope needed temporal help for this endeavour, certainly the goal of his call for help from Tuscany. The letters below elaborate both exhortations to deepened spirituality and specific requests for temporal help.

23.Noffke's dating of Catherine's letters is the most reliable to date and was only finished with the 2008 publication of the fourth and final volume of the translated letters. Thus, it is only recently that one can state that most of Catherine's crusade letters. Thus, it is only recently that one can state that most of Catherine's crusade
letters were written after Gregory XI sent out his request to Tuscan ecclesiastical authorities.

\section{Count of Monna Agnola and Niccolò dei Strozzi}

Catherine encouraged two knights connected to the Tuscan Hospitallers. $^{24}$ Both letters show how Catherine wove together her wisdom regarding transformation and her brand of crusade spirituality, adapting her rhetoric to each recipient, using images and metaphors related to the task of a knight. Also shown in these letters is Catherine's wisdom regarding vocation.

Catherine starts the letter to a young Florentine count by urging him to fight vice and acquire virtue; 'Christ the captain' leads the battle against the enemy, namely, vices; the count should follow the captain in this fight. Always focused on her spirituality of transformation to capacity for love and desire for the good of others, she asserted that as transformation through growth in virtue takes place, God will transform desire, in this case, infuse a hunger for the conversion of 'unbelievers', that is, the Turks holding the Holy Land.

Catherine believed that part of each person's journey of transformation involved recognising the particular task, role and/or vocation to which God called them and carrying this out as a response to the encounter with God's love. In the case of the count and his companions, Catherine was convinced God called them to become crusaders, joining the Hospitallers. Note the certainty Catherine expressed about God's will for others and the authoritative style with which she communicated this:

It seems to me that God's immeasurable goodness has elected you knight to fight against vice and sin, [his own] so that you might acquire the treasure of the virtues. Now, I believe God invites you to grow and to activate your perfection by giving you a hunger for the spiritual wellbeing of the unbelievers. It seems he would like you to be among the first Hospitallers to come against them now that the crusade is starting. The Holy Father sends the Hospitallers and anyone following them against the unbelievers. (Letter 257)

Transformation through growth in virtue would birth within the count the desire that would make him a good crusader. This is an example of Catherine's teaching about transformation of desire. ${ }^{25}$

Catherine advised Niccolò, prior of the Tuscan Hospitallers, that the crusade is a spiritual journey as much as a holy war. Using language suitable for a knight, she asserted that Niccolò should be armed with love of virtue and hold the knife that cuts out vice. She urged conversion from selfish self-love towards capacity to love as Jesus loved for the good of the other. For such love was not only the ultimate value of a spiritual journey but was also essential in order to be an effective warrior. Transformation away from selfish self-love would lead Niccolò to desire to contribute to the conversion

\footnotetext{
24.The Hospitallers, a religious order of knights founded in the 12 th century to fight the crusade became the last rest in Gregory Xl's effort to promote acrusade. The spirituality were written by Bernard of Clairvaux; see Pernoud (1991).
}

25.On Catherine and transformation of desire, see Villegas (2017). 
of the 'unbelievers', and to desire the ultimate giving of self, namely, martyrdom (Letter 256):

With desire to see you a manly knight, for a knight who must fight in the battlefield, must be armed with the weapons of love, which is the most potent weapon possible. It is not enough that a man be armed only with shields and mail, for if he does not possess the weapons of love and related desire for honour and for the cause for which he is fighting, as soon as he faces his enemies he would fear and turn back. (Letter 256)

We see in this passage, Catherine's conviction that transformed capacity for love is crucial to any endeavour, including the capacity to fight well. Remarkably, she had no qualms about offering advice in authoritative rhetoric regarding attitudes required to be a warrior on the battlefield; transformation in capacity to love and the related transformation of desire were important for the task of warrior, not just for personal holiness.

Conversion from worldly excesses and attachments was important to being an effective knight, because love for worldly honour and pleasures such as good food and drink, and attachments to riches were 'weapons of death' that impeded facing attacks in war:

It is important that you go forth not only with the armour of war for your body but with spiritual armour as well; for if you do not have the armour of the honour of God and the desire to conquer the city of the wretched infidel souls who do not participate in the blood of the lamb, the fruit acquired with the weapons of war would be minimal. (Letter 256)

Catherine ties the above exhortations to a spirituality of martyrdom. A knight on a path of transformation through relationship with Christ should be ready to be a martyr. She tells Niccolò, 'you have been called to the state of the glorious martyrs, called to give your life for Christ crucified' (Letter 256). And then she ends her letter with the assurance and certainty that she knows God's will for him, which is also her will: go forth with the cross as your shield and be willing to be a martyr:

My desire is to see you become a true knight ... I hope that through the infinite and immeasurable goodness of God you will fulfil his will, which requires this of you, and this is my will as well ... Bathe yourselves in the blood of Christ crucified, hide in his sweet wounds and take as shield the most holy cross. (Letter 256)

\section{Correspondents on worldly path}

The correspondents discussed so far were all persons who had an active desire to be good Christians, whereas those who follow were unlikely to have been committed to their Christian faith; nevertheless, Catherine addresses all with the same call to a relationship with the God of love who transforms, evidencing a missionary characteristic in her appeals.

\section{Hawkwood, professional soldier}

John Hawkwood, an Englishman, was a professional soldier who had been employed alternatively by various sides of the conflict in Italy, from Gregory XI to his enemy, Bernabò Visconti of Milan. At the time Catherine wrote, Hawkwood was not allied with the pope's cause ${ }^{26}$; thus, she sought to persuade him to stop fighting against the Papal League and instead join the crusade. In this way, he would also be choosing salvation. We can assume Hawkwood was not devoted to Christian practice and less so to a journey of relationship with God. Nevertheless, Catherine authoritatively insisted that God ordered and the pope commanded that warriors join a crusade, and amazingly invited him to consider giving his life for Christ:

I want to see you true son and knight of Christ, that is that you would desire many times over to give your life for sweet Jesus if necessary ... Because God and also the Holy Father have ordered war against the unbelievers. You who derive so much pleasure from war and fighting, cease attacking other Christians; with these acts you offend God. Rather go against the unbelievers. For it is a great cruelty that we who are Christians, bound together in the body of Holy Church, should persecute one another ... Be willing to give your life for Christ and in this way show that you are manly and a true knight. (Letter 140)

\section{Bartolomeo Lord of San Severino, knight}

Catherine wrote to Bartolomeo, lord of a fortified town located strategically west of Tuscany. He was a young knight who had led successful campaigns in the entangled conflicts between City States, having fought on both the papal and antipapal sides. At the time Catherine wrote to him, his allegiance to the pope was strategically important to the pope's cause (Gardner 1907:139, 189, 407).

Catherine first exhorted Bartolomeo to a life of transformation through the experience of God's love. In this letter, we note another major theme in Catherine's wisdom, namely, that we are created in the image of God, and as such, we are created out of love and to love:

Think about this, dear father, since we were created in the image and likeness of God out of love, the first clothing we had was love; and so persons cannot live without love, as we are made of love and nothing else; what we have in terms of both our body and our soul is for love. (Letter 384; Gardner I in Noffke translation)

Perhaps naively presuming that Bartolomeo indeed began a journey to know God's love, Catherine urged him in the name of Christ crucified to respond immediately to the pope's appeal. She assured him that union with God, and therefore reception of Christ's life (the blood of Christ) would eliminate fear. For fear would impair the task of warrior and prevent willingness to die for the sake of liberating the Holy Land:

I invite you, do not be negligent, do not delay when you receive the invitation, when the Holy Father raises the standard of the holy cross ordering the holy passage. No one should avoid or escape this call; he should not fear death ... I want to see you a fearless, manly knight; the blood will encourage you, fortify you and remove all fear. (Letter 384, Gardner I, Noffke translation)

26.On Hawkwood's involvement in the wars between the Papal States and the Italian City States, see Luongo (2006:82-87, 159). 


\section{Tommaso d'Alviano, professional soldier}

Catherine asked d'Alviano, a mercenary captain, to join forces in the cause of the pope, bringing his troops and resources with him. Her epistle starts with an exhortation to know God's love and to allow this knowledge to unfold into converted desire for God's will. In this way, d'Alviano would be able to recognise his call as servant to the church in her time of need. Catherine then presses her wisdom about vocation. God is served through different vocations, namely, the ordinary life of most persons, the sacred service of priests and through persons chosen for special service to the church in time of need; the latter was d'Alviano's vocation, Catherine authoritatively assures him:

I think God has chosen you to be a faithful servant in God's great need [the battle for papal allegiance of Italian city states and the crusade]. This service is so pleasing to God that it is beyond explaining ... Oh what a great grace God has given you and all who serve him. (Letter 191)

As response to this grace, d'Alviano should bathe himself in the blood of Christ crucified in order to have the ability to make 'sweet' peace and after this peace 'we shall all gather against the unbelievers' (Citations Letter 191). Note again Catherine's insistence that connection to God's love and the ensuing transformation are also necessary for fighting as a successful knight in the service of the church.

\section{To civil authorities}

\section{Giovanna of Naples}

In three letters written in 2 months, Catherine exhorted Giovanna, Queen of Naples, to join the pope's cause and send resources and troops to the crusade. Giovanna was known to use her power to punish and control arbitrarily, including having people unjustly put to death; she was not known for her marital fidelity. Catherine would almost certainly have known this through Raymond who was from Naples. Nevertheless, she remarkably exhorted Giovanna in all three letters to engage in a spiritual journey and even invited her to consider giving her life for Christ in the crusade.

Catherine's first letter starts with a particularly lengthy exhortation to a life of relationship with God, including urging Giovanna to embrace the cross with her deepest self, that is, she should plant the cross in her soul, also alluding to assisting the crusade as 'planting the cross' was a term used for the holy passage:

In the name of sweet Christ Jesus, I beg you to raise your desire, all your affectivity, your love, to the holy cross and to carry it and plant it in the garden of your soul, for the cross is a tree full of the fruit of true and real virtue. That you may see clearly that besides union to human persons, God united himself to the cross; he desires and requires that we unite ourselves out of desire and love to this sweet tree so that our garden might bear only sweet, soft fruit. (Letter 138)

This passage articulates Catherine's wisdom regarding transformation of desire, the motivational drive in the depth of the person that makes possible seeing and acting according to God's will. Through such an inner process, Giovanna would be a faithful daughter of the church for her own salvation and the church's cause. Furthermore, Catherine reminds Giovanna of the Christian's duty to take back the places where Christ lived and died. ${ }^{27}$ 'Out of desire and love, raise within you the standard of the holy cross because the Holy Father intends to raise it over the Turks' (Letter 138).

Catherine minced no words. Not only should Giovanna see that it is God's will to support mother church, but she would be foolish and stupid if she did not offer support by joining the crusade. Note the authoritative exhortation to this woman who is queen:

I ask and press on behalf of Christ crucified that you support the Bride of Christ in her need showing that you are a faithful daughter of sweet, Holy Church ... You should know that this mother nourishes her children at the breast with sweet, life giving milk. Stupid and foolish is the child who would not help her mother. (Letter 138, [author's own italics])

In another letter - with authoritative confidence that she knows God's will - Catherine urged:

I ask and press [my emphasis] you on behalf of Christ crucified to offer any and all needed strength and help so that the Holy places of our sweet Saviour are taken away from the unbelievers, and that their souls may be rescued from the evil one so that they too may participate, as do we, in the blood of God's Son. (Letter 133)

Catherine does not stop at pressing Giovanna to join the pope's cause and offer resources for the crusade. Amazingly, she enjoins Giovanna to a desire for martyrdom using the language from martyr spirituality that moved Catherine herself, namely, 'giving blood for blood':

You could show God no greater love and sacrifice than to ready yourself, if necessary, to give your life for Christ crucified. Oh! how sweet it would be to offer blood for blood, to see you grow in holy desire as a result of remembering the blood poured out by God's son. (Letter 143)

\section{Charles V of France}

While on her mission to Avignon, Catherine was introduced to Louis of Anjou, brother of Charles V of France. Louis asked Catherine to write to his brother encouraging him to provide resources and men for a crusade..$^{28}$ As in all her crusade letters, Catherine begins her missive with an exhortation to transformation. Charles should not be attached to worldly possessions and honour; he should act as if all is on loan. Acting justly is a key virtue required by God; therefore, Charles must avoid acting unjustly for the sake of pleasing others. Most of all, Charles should meditate on Jesus crucified, for this event offered the greatest lesson about love and loving others as Jesus does. Learning this 27.See no. 14 for references on crusade spirituality.

28.Louis motivation for this request is unknown (Luongo 2006:173). Noffke indicates the letter may not have reached Charles (Catherine of Siena 2000-2008:I.219). Citation to volume and page. 
through a spiritual journey should be Charles' most important task in life.

Catherine then pressed Charles to pursue the crusade. He should follow the crucified and show his love for God 'by following this holy cross in the holy and sweet holy passage'. Indeed, Catherine desired that 'the fire of holy desire grow in you to follow the cross' (Citations, Letter 235) so that Charles can have the motivation to pursue this cause. Catherine gave Charles very specific advice:

Stop [the war with England] for the love of Christ crucified! Have you not considered how much you will be the cause of evil if you don't do what you can? Evil for Christians and evil for the unbelievers because your fight has stalled and is stalling the mystery of the holy passage ... I beg you not to continue to be the cause of so much evil and to obstruct the good of recovering the Holy Land and so many souls that participate in the blood of the Son of God. You should be ashamed of this, you and other Christian leaders ... permit war of brother against brother while assisting the enemy [the Turks occupying the Holy land, and moving to take over parts of eastern Europe] ... Make, make, make peace and send all war to the unbelievers! (Letter 235)

Catherine has no misgivings or reserve in offering advice about war to a king. Out of her own deep experience of God's love and her long journey of transformation, she was certain and confident that she was in touch with God's will. And God's overarching will is the salvation of God's children. For Catherine, this meant God wanted the salvation of European warriors and knights, and that required that they stop fighting each other, make peace among themselves and instead devote themselves to recovering the Holy Places from the Turks; and in the process offer these 'unbelievers' the possibility of salvation through conversion to knowledge of Christ.

\section{Bernabò Visconti}

Catherine sought to win over Bernabò Visconti, head of state of Milan and surrounding region; he was a long-time enemy of the papacy with a reputation for a less than ordered life. Visconti had sought to create a league of City States that would remain independent from the Papal States. Enlisting his help for a crusade would be a key strategic move.

Despite his reputation, Catherine exhorted Bernabò to transformation of desire by urging him to participate in the blood. Jesus offers us freedom through his redemptive death on the cross, expression of his love, which Bernabò must taste experientially. This required going within, for we are lords of our soul where God rests. Bernabò must take charge of his free will and choose to encounter God within in order to find freedom to choose the good. Bernabò should act as created out of love, entering into a relationship with God to be bathed in the blood which would give him the conversion and strength to respond to the pope's call for a crusade. This call involved helping to liberate the Holy Places and facilitate the conversion of the 'unbelievers'. First, though, Bernabò must turn away from the sin of punishing priests, who, if necessary, will be punished directly by God: ${ }^{29}$

I want you to be a faithful son of holy church, bathing in the blood of Christ crucified so you can be a committed and not a rotten member of holy church. In this way you will obtain so much strength and freedom that no human or evil power can take these away from you and you will no longer be enslaved by the mortal sin of rebellion against holy church. You will be made strong by the fortitude of grace ... And so, I now invite you on behalf of Christ crucified to make a true and perfect peace with our good father, Christ on Earth [the pope], and instead make war against the unbelievers. You should be disposed to offer Christ crucified material goods, as well as your body. (Letter 28, [author's own italics])

Note that even Bernabò, a cunning worldly, powerful lord, is invited to offer his body to Christ, that is, desire martyrdom.

\section{To family members of civil authorities}

Catherine wrote to family members of temporal authorities expecting them to convince their relative. Among others, she wrote to Elizabeth, Queen of Hungary, the mother of Louis of Hungary (Letter 145). The latter was essential to Gregory XI's crusade effort as Hungary was well positioned to defend the Balkans where the Turks were expected to enter into Europe..$^{30}$ Catherine also wrote to Regina della Scala, wife of Bernabò Visconti. The first part of these letters includes lengthy appeals - similar to those already described - to enter into relationship with God and learn about God's love. These exhortations evidence again Catherine's conviction that persons must be on a journey of transformation in order to respond to her requests for support of the church's policies.

Particularly remarkable is the letter to Regina della Scala. She was known as 'an imperious, avaricious, ambitious, and treacherous woman' (Catherine of Siena 2000-2008:IV, 402 ). Yet, Catherine wrote her one of her longest letters (2200 words) elaborating most of the elements of her wisdom about the spiritual journey. Only a brief section at the end is devoted to persuading Regina to pressure her husband.

\section{Catherine first urges a relationship with God:}

When we have found where love is found ... she nourishes herself at the fire of love [God], because she has known herself so loved ... And so I want you to grow in true, holy desire to follow this path. Doing so you will fulfil the desire and will of God within you, who wants nothing other than your transformation. (Letter 29)

Having enjoined Regina to pursue this spiritual path, Catherine adapts her wisdom to the experience of married love in order to persuade Regina to pressure her husband:

I am certain that if you have the virtue of charity [love], it would be impossible for your husband to not feel the heat from such

29. Bernabo felt aggrieved by his excommunication for his opposition to papal authority at the same time that he sought control over clergy and church property. Catherine strongly believed that priests as mediators of salvation were not to be punished or attacked by lay persons. God would judge them. See Catherine of Siena (1980: especially sections 115-117) and Letter 191.

30.A Turkish force had captured Macedonia in 1371, thus reaching the border with European Hungary. See Thiebault (1985:314). 
love. First Truth [God] wants it this way, that you two should be united in spirit and in affetto ${ }^{31}$ and holy desire ... I want you to follow this way of leading your husband to virtue and to the path of truth. When you are able, invite him and beg him to be obedient to the Holy Father that he may be a true son and servant of Christ crucified. (Letter 29)

To this worldly woman, Catherine writes that if she is connected to God's love, then God's love will shine through in the love for her husband. Through her, God's love can work in her husband and bring him conversion to see that for his salvation he must follow the pope's policies, including joining the crusade. This letter highlights Catherine's missionary zeal, for it is hard to imagine Regina as a receptive candidate for these exhortations.

\section{Concluding discussion \\ Political and cultural context important for spiritual journey}

While Catherine's crusade letters did not accomplish her religious intent or the related political goal, they evidence a number of important aspects of her spirituality. First, they demonstrate her belief that social context mediated the journey to transformation. ${ }^{32}$ Catherine's belief in the importance of social context for the individual spiritual journey is highlighted in the passionate conviction with which she addressed persons in all walks of life with possible influence on the crusade, whether they were already persuaded to focus on the God of love or not, whether sinful warriors or unfaithful monarchs. It was her prophetic mission to bring wisdom - God's word, as did the Old Testament prophets - to all who influenced the social context, that is, mercenary knights, lords of fortified cities, leaders of large City States, Kings and Queens, or the relatives of those in significant positions of power. She must exhort these persons for the sake of their own salvation, certainly, but in this case, because their choices and acts could affect a societal context with potentially widespread effects on the possibility for salvation.

Despite these passionate appeals, Catherine's letters did not accomplish their political purpose, that is, modifying the context for salvation. There is no evidence that her letters to those who were strategic to helping the pope with his crusade efforts were persuasive; some letters may not have been received (e.g. to Charles V) or read. None of her followers joined a holy passage pilgrimage. Nor did her letters accomplish her religious goal. It is unlikely that any of her correspondents - other than her followers and the two knights already persuaded to pursue the crusade were moved by her exhortations to a journey of relationship

31.Affetto is Catherine's word for that which moves the person from the core of her being. It is related to desire but means much more. For a discussion of affetto, see Villegas $(2017: 6,7)$.

32.Catherine's overarching focus and concern with salvation and transformation is detailed in the first article of this series (Villeagas 2021). with God. ${ }^{33}$ One cannot imagine correspondents such Hawkwood, Giovanna, Regina or Bernabò pursuing Catherine's exhortations.

How can we interpret the fact that Catherine's crusade letters are unlikely to have had an effect, especially when she so passionately and forcefully states she was writing to pursue God's will and so authoritatively told her correspondents that the actions she was calling them to take were God's will? One interpretation is that Catherine's spirituality had a missionary and prophetic quality, that is, she exhorted others to that which she saw as God's will for individuals and society irrespective of how she would be heard. She did not engage in calculations regarding the effectiveness of her word to particular correspondents, though her messages were targeted to their roles. Her passion was to announce God's message of transformation/salvation as Old Testament prophets were called to speak God's word irrespective of reception.

There are other concurrent interpretations. Noffke (1996:55) suggests Catherine was politically naïve. While this is likely, it does not change the reality of her prophetic and missionary motivation. That Catherine's letters were not effective in accomplishing their intended goals also raises the question of what this tells us about her discernment of God's will. This will be the topic of the third paper in this series.

\section{The crusade letters window into how Catherine lived her wisdom}

In terms of how Catherine lived her beliefs, these crusade letters are a remarkable, concrete witness to the manner in which God acted in her and through her and how she interpreted that experience into a timeless wisdom. God's transforming presence of love works in particular persons with their natural gifts and personality. Catherine was intelligent (Vauchez 2018:57) and clearly had a strong, authoritative personality, perhaps the most remarkable trait seen in her crusade letters. She wrote with a confidence and authority to persons in power that is astonishing when one considers that Catherine had no authority in her medieval context: she was not a noble woman, she was not married and she was not an abbess or even a nun. She was an unmarried, uneducated woman belonging to a penitential lay order. Such a person had little status in medieval times. Yet, she had the freedom to write with lack of selfconsciousness and great authority to the highest temporal and ecclesiastical authorities. This is a witness to Catherine's union with God, to her wisdom about transformation of the core of oneself through knowledge of God and self so that one's affetto, that is, the core of one's motivation and thought are as congruent as possible with God's perspective. Her natural gifts and freedom were empowered by this union and nurtured a remarkable conviction that she was connected to God and could, therefore, interpret God's will to others.

33.In Villegas (2021:4-8), we saw that Gregory XI was not persuaded by Catherine to action on particular policies, but her attempts to form him in terms of his spiritual action on particular policies, but her attempts to form him in terms of his spiritual
journey are likely to have had some effect, for Gregory XI respected Catherine's holiness and had an interest in the spiritual life. 
The crusade letters offer a concrete example of this dynamic of Catherine's spirituality, a dynamic already highlighted in the first article of this series (Villegas 2021).

Finally, the letters analysed above leave us a major testimony to the way Catherine applied her wisdom, integrating it to a spirituality of vocation and to her innovative combination of crusade and martyr spirituality as an expression of giving of self to God.

\section{Implications for today}

Catherine's medieval spirituality reminds us that the journey of transformation occurs in a cultural context. How do contemporary social contexts influence our spiritual journeys? The call to speak and act prophetically is a basic biblical tenet. What would a spirituality that took this seriously look like today? Through her core wisdom, she reminds us again about the need for transformation in order to perceive God's path and act accordingly.

\section{Acknowledgements Competing interests}

The author declares that she has no financial or personal relationship(s) that may have inappropriately influenced her in writing this article.

\section{Author's contributions}

D.L.V. is the sole author of this research article.

\section{Ethical considerations}

This article followed all ethical standards for research without direct contact with human or animal subjects.

\section{Funding information}

The author received financial support for the publication of this article from the University of the Free State.

\section{Data availability}

Data sharing is not applicable to this article as no new data were created or analysed.

\section{Disclaimer}

The views and opinions expressed in this article are those of the author only and do not reflect the policy or position of any affiliated institution.

\section{References}

Barrett, J. \& Lukowski, A.A., 2008, 'Wedded to light: The life, letters, and legend of St Catherine of Siena', The Journal of the Midwest Modern Language Association 41(1), 1-9. https://doi.org/10.2307/20464245

Beattie, B., 2011, 'Catherine of Siena and the papacy', in C. Muessig, G. Ferzoco \& B. Kienzle (eds.), A companion to Catherine of Siena, pp. 73-98, Brill, Leiden.

Blake, E.O., 1970, 'The formation of the "crusade idea"', Journal of Ecclesiastical History 21(1), 11-31. https://doi.org/10.1017/S0022046900048429

Bouyer, L., 1960, The spirituality of the New Testament and the Fathers (History of Christian spirituality), vol. 1, Desclee, New York, NY

Catherine of Siena, 1980, The dialogue, ed. and transl., S. Noffke, Paulist, New York, NY.

Catherine of Siena, 2000-2008, The letters of Catherine of Siena, 4 vols., ed. and transl., S. Noffke, Arizona Center for Medieval and Renaissance Studies, Tempe, AZ.

Catherine of Siena, 2002, 'Lettere', in A. Volpato (ed.), Opera omnia, testi e concordanze, Provincia Romana dei Frati Predicatori, Centro Riviste, Pistoia, viewed n.d., from

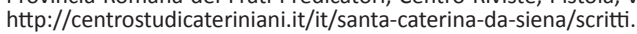

Catherine of Siena, 2016, Lettere, edizione critica e commento, ed. A. Volpato, Centro internazionale di studi cateriniani, Rome, viewed n.d., from http://www. centrostudicateriniani.it/en/st-catherine-of-siena/writings.

Coakley, J.W., 2006, Women, men, and spiritual power: Female saints and their male collaborators, Columbia University, New York, NY.

Flood, B., 1974, 'St Bernard's view of crusade', Cistercian Studies 9(1), 22-35.

Gardner, E.G., 1907, Saint Catherine of Siena: A study in the religion, literature, and history of the fourteenth century in Italy, J.M. Dent \& Co., London.

Luongo, F.T., 2006, The saintly politics of Catherine of Siena, Cornell University, Ithaca, NY.

Luongo, F.T., 2012, 'The historical reception of Catherine of Siena', in C. Muessig, G. Ferzoco \& B.M. Kienzle (eds.), A companion to Catherine of Siena, pp. 23-45, Brill, Leiden.

McDermott, T., 2007, 'Catherine of Siena's teaching on self-knowledge', New Blackfriars 88(1018), 637-648. http://doi.org/10.1111/j.1741-2005.2006.00130.x

McDermott, T., 2008, Catherine of Siena: Spiritual development in her life and teaching, Paulist, New York, NY.

McGinn, B., 2012, The varieties of vernacular mysticism, 1350-1550, Crossroad, New York, NY.

Merton, T., 2008, 'From pilgrimage to crusade', Cithara 48(1), 5-21.

Noffke, S., 1996, Catherine of Siena: Vision through a distant eye, Liturgical, Collegeville, PA.

Noffke, S., 2011-2012, Catherine of Siena: An anthology, 2 vols., Arizona Center for Medieval and Renaissance Studies, Tempe, AZ.

Pernoud, R., 1991, 'Templiers', Dictionnaire de spiritualité, online edn., vol. 15, col. 152, viewed 16 May 2020, from http://www.dictionnairedespiritualite.com/appli/ article. php?id=10205.

Portnykh, V., 2017, '“L” argument vassalique' au service de la prédication des croisades en terre sainte (fin XIle - XIIle siècles)', Medieval Sermon Studies 61(1), 59-72. http://doi.org/10.1080/13660691.2017.1368578

Raymond of Capua, 1980, The life of Catherine of Siena, transl. C. Kearns, Glazier, Wilmington, $\mathrm{NC}$

Rordorf, W. \& Solignac, A., 1980, 'Martyre, II: Théologie et spiritualité du martyre, Permanance du martyre dans l'église', Dictionnaire de spiritualité, online edn., vol. 10, col 718, viewed from http://www.dictionnairedespiritualite.com/appli/article. php?id $=6173$.

Rousset, P., 1975, 'Sainte Catherine de Sienne et le problème de la croisade', Revue Suisse d'Histoire 25(4), 499-513. http://doi.org/10.5169/seals-80733

Thiebault, P., 1985, 'Pope gregory XI (1370-1378) and the crusade', Canadian Journal of History 20(3), 313-336. http://doi.org/10.3138/cjh.20.3.313

Vauchez, A., 2018, Catherine of Siena: A life of passion and purpose, transl. M.F. Cusato, Paulist, New York, NY.

Viglione, M., 2014, 'Esigenza di pace, prospettive di missione e idea di crociata nelle lettere di santa Caterina da Siena', Revue d'Histoire Ecclésiastique 109(1-2), 91-122. http://doi.org/10.1484/J.RHE.1.103886

Villegas, D.L., 2013, 'Catherine of Siena's wisdom on discernment and her reception of scripture', Acta Theologica 32(2S), 209-227. https://doi.org/10.4314/actat.v32i2S.12

Villegas, D.L., 2017, 'Continuous prayer in Catherine of Siena', HTS Teologiese Studies/ Theological Studies 73(3), a4611. http://doi.org/10.4102/hts.v73i3.4611

Villegas, D.L., 2021, 'Catherine of Siena's spirituality of political engagement', HTS Teologiese Studies/Theological Studies 77(4), a6319. https://doi.org/10.4102/hts. v77i2.6319/ 